\title{
CAMA
}

Centre for Applied Macroeconomic Analysis

\section{How Does the Sensitivity of Consumption to Income Vary Over Time? International Evidence}

\section{CAMA Working Paper 22/2016 May 2016}

Ergys Islamaj

Development Prospects Group, World Bank

\section{Ayhan Kose}

Development Prospects Group, World Bank

Brookings Institution

CEPR and

Centre for Applied Macroeconomic Analysis, ANU

\section{Abstract}

This paper studies how the sensitivity of consumption to income has changed over time as the degree of financial integration has risen. In standard theory, greater financial integration facilitates international borrowing and lending, helping to reduce the sensitivity of consumption growth to fluctuations in income. We examine the empirical validity of this prediction using an array of indicators of financial integration for a large sample of advanced and developing countries over the period 1960-2011. We report two main results. First, the sensitivity of consumption to income has declined over time as the degree of financial integration has risen. The decline has been more pronounced in advanced economies than in developing ones. Second, our regression analysis indicates that a higher degree of financial integration is associated with a lower sensitivity of consumption to income. This finding is robust to the use of a wide range of empirical specifications, country-specific characteristics and other controls, such as interest rates and outcome-based measures of financial integration. We also discuss other potential sources of the temporal changes in the sensitivity of consumption to income. 


\title{
Keywords
}

Consumption Sensitivity, Financial Integration, Risk Sharing, Intertemporal Smoothing

\author{
JEL Classification
}

E21, F02, F4

Address for correspondence:

(E) cama.admin@anu.edu.au

ISSN 2206-0332

The Centre for Applied Macroeconomic Analysis in the Crawford School of Public Policy has been established to build strong links between professional macroeconomists. It provides a forum for quality macroeconomic research and discussion of policy issues between academia, government and the private sector.

The Crawford School of Public Policy is the Australian National University's public policy school, serving and influencing Australia, Asia and the Pacific through advanced policy research, graduate and executive education, and policy impact. 


\title{
How Does the Sensitivity of Consumption to Income Vary Over Time? International Evidence
}

\author{
Ergys Islamaj and M. Ayhan Kose*
}

April, 2016

\begin{abstract}
This paper studies how the sensitivity of consumption to income has changed over time as the degree of financial integration has risen. In standard theory, greater financial integration facilitates international borrowing and lending, helping to reduce the sensitivity of consumption growth to fluctuations in income. We examine the empirical validity of this prediction using an array of indicators of financial integration for a large sample of advanced and developing countries over the period 1960-2011. We report two main results. First, the sensitivity of consumption to income has declined over time as the degree of financial integration has risen. The decline has been more pronounced in advanced economies than in developing ones. Second, our regression analysis indicates that a higher degree of financial integration is associated with a lower sensitivity of consumption to income. This finding is robust to the use of a wide range of empirical specifications, country-specific characteristics and other controls, such as interest rates and outcome-based measures of financial integration. We also discuss other potential sources of the temporal changes in the sensitivity of consumption to income.
\end{abstract}

Key Words: Consumption Sensitivity, Financial Integration, Risk Sharing, Intertemporal Smoothing

JEL Codes: E21, F02, F4

*Islamaj: Development Prospects Group-World Bank; eislamaj@worldbank.org. Kose: Development Prospects Group-World Bank, Brookings Institution, CEPR and CAMA; akose@worldbank.org. We would like to thank Mario Crucini, and an anonymous referee for their detailed feedback that has significantly improved the paper. We also thank Woon Gyu Choi, Masahiro Kawai, Paul Ruud, Kwanho Shin, Dana Vorisek, and participants of the Bank of Korea- IMF Conference on "Future of Asian Finance: Financial Integration and Implications for Macroeconomic Performance in the Region". A slightly shorter version of this paper will soon be published in the Journal of Economic Dynamics and Control. The views expressed in this paper are those of the author(s) and do not necessarily represent those of the World Bank Group, its Board of Executive Directors, or the governments they represent. 


\section{Introduction}

Consumption constitutes a significant fraction of income, surpassing two-thirds in many countries. Numerous studies examine the sensitivity of consumption to changes in income. These studies often rely on the life-cycle permanent income hypothesis (PIH), which offers analytical tractability and predicts that anticipated changes in income should have no effect on consumption because they are assumed to be already internalized. And yet, the modelling of consumption behavior is still a challenge as research finds significant evidence for the excess sensitivity of consumption to income, rejecting the PIH and suggesting the importance of credit constraints (Jappelli and Pistaferri, 2010).

Standard theory predicts that financial integration would facilitate international borrowing and lending in response to shocks, thus lowering the sensitivity of consumption to income changes. Specifically, reducing restrictions on international financial transactions should allow countries to borrow and lend amongst each other, reducing the sensitivity of consumption to transitory changes in income. With the growth and integration of international equity markets, agents would also be able to smooth consumption ex-ante across different states of nature. ${ }^{1}$ Given these benefits, more financially integrated economies are expected to have a lower sensitivity of consumption to income.

A vast empirical literature has concluded that consumption co-moves with income in international data, suggesting that risk sharing across regions and countries remains incomplete. ${ }^{2}$ Obstfeld (1994), Crucini (1999), Crucini and Hess (2000) and Asdrubali and Kim (2008) study income and consumption dynamics across regions and advanced countries, and report two important findings. First, consumption remains sensitive to income shocks and risk sharing is far from complete. Second, the degree of intertemporal smoothing as well as risk sharing tends to be larger within than across countries.

In a related paper, Ostergaard, Sorensen and Yosha (2002) find that consumption and disposable income for U.S. states and Canadian provinces exhibit higher excess sensitivity when not controlling for aggregate income fluctuations. They conjecture that this result may be explained by closedeconomy constraints, such as the degree of financial integration. Lewis (1997) examines the impact of financial integration on the sensitivity of consumption to income. Following the interpretation by Campbell and Mankiw (1989), she considers the sensitivity of consumption to income as a measure of the proportion of agents who are "liquidity-constrained". ${ }^{3}$ She concludes that, consistent with the predictions of theory, a higher degree of financial integration tends to be associated with a lower proportion of liquidity-constrained agents.

But, how has the sensitivity of consumption to income changed over time as the degree of financial integration has risen? Despite the sizeable literature on the sensitivity of consumption to changes in income and the rapid increase in the volume of international financial flows over the past

\footnotetext{
${ }^{1}$ Kose, Prasad, and Terrones (2009) provide a review of the literature.

${ }^{2}$ See Obstfeld (1994) and Lewis (1996) for early studies on the topic. Some researchers study deviations of consumption from perfect risk sharing. For example, Cochrane (1991) and Mace (1991) focus on individual income and consumption dynamics, and Crucini (1999) studies the extent of incomplete risk sharing for U.S. states, Canadian provinces and the G-7.

${ }^{3}$ Campbell and Mankiw (1989) use a simple approach of regressing consumption growth on income growth and interpret the coefficient on the latter as the proportion of agents who are liquidity constrained. Following their seminal work, many studies have incorporated liquidity-constrained agents into their models to explain the high correlation between consumption and income growth (Mankiw, 2000; Gali, Lopez-Salido, and Valles 2007; Kollmann, 2012, 2015).
} 
three decades, this question has been largely unanswered. We utilize a more direct approach than the earlier studies to investigate the relationship between financial integration and the sensitivity of consumption to income fluctuations. We focus on the role of financial integration as a possible driver of the temporal changes in the sensitivity of consumption to income while also providing a broader discussion of other possible structural interpretations of these changes.

Our paper makes three major contributions to the literature. First, we study the sensitivity of consumption to income using a unified framework and a rich dataset covering 88 countries for the 1960-2011 period. Second, we document how this sensitivity has changed over time and across groups of countries as the degree of financial integration has increased. ${ }^{4}$ Third, we provide a broader perspective than earlier studies by discussing alternative, theoretically appealing explanations for the empirical phenomenon we document. Specifically, we discuss the potential roles played by a wide range of factors, including changes in the persistence and cross-country correlations of income shocks, transitory and permanent components of expected income, the convergence of interest rates, and ex-ante pooling of risk across countries in explaining the declining sensitivity of consumption to income over time.

We report two main findings. First, the sensitivity of consumption to income has declined over time as countries have become more financially integrated. Specifically, the sensitivity of consumption growth to income growth decreased in the 1990s and the first part of 2000s for advanced economies and developing countries. While both advanced and developing economies have experienced a fall, the decline has been larger in advanced economies than in developing ones.

Second, our regressions show that a higher degree of financial integration is associated with a lower sensitivity of consumption to income. This finding is robust to the use of different specifications, country groups and various controls, such as interest rates, and outcome-based measures of financial integration. These results are not driven by country-specific characteristics, including those related to trade integration and financial sector development.

Our study also provides a benchmark set of results that should be useful to future studies on the linkages between consumption and income, and for calibration of general equilibrium models that incorporate liquidity constrained (rule-of-thumb) agents. A number of studies in the openeconomy macroeconomics literature have analyzed the roles of rule-of-thumb agents using dynamic general equilibrium models but the empirical literature offers little guidance as to what should be the proportion of the rule-of-thumb agents in such models. ${ }^{5}$ Instead, these studies mostly rely on the estimates by Campbell and Mankiw for the U.S. in their calibrations. Our estimations with international data indicate that the proportion of rule-of-thumb agents is higher than those based on the U.S. data.

The remainder of the paper is structured as follows. The next section briefly describes the database and empirical framework we employ. Section 3 documents the sensitivity of consumption

\footnotetext{
${ }^{4}$ Lewis (1997) employs a data sample that ends in 1993, so it does not cover much of the period that has witnessed a sharp increase in the degree of financial integration we are able to consider here. In addition, her work only takes into account simple binary measures of financial integration. Recently available measures of financial integration we employ here make it possible to better capture the relationship between financial integration and the responsiveness of consumption to income fluctuations.

${ }^{5}$ Following Mankiw (2000), rule-of-thumb agents have been incorporated in closed economy DSGE models to study fiscal and productivity shocks (Gali, Lopez-Salido and Valles, 2007; Bilbiie, 2008). More recently, a few studies have emphasized their importance in explaining certain puzzles in international business cycle literature (Gao, Hnatkovska and Marmer, 2014; Kollmann, 2012, 2015).
} 
to income and its temporal evolution. Section 4 analyzes the linkages between financial integration and the sensitivity of consumption to income, and undertakes a battery of robustness tests. Section 5 provides a discussion of alternative explanations. Section 6 offers some concluding remarks.

\section{Database and Econometric Framework}

\subsection{Database}

We examine the evolution of the sensitivity of consumption to income changes using a rich database that includes 88 countries, including 22 advanced and 66 developing economies, over the period 1960-2011 for our baseline specification. The database includes time-series of income, consumption, measures of financial integration, world and country specific interest rates, and variables capturing various country-specific features. ${ }^{6}$

The data series for income and consumption are from the Penn World Tables (PWT 8.1). Per capita real income and per capita consumption correspond to the measures of national output and private consumption, respectively. It is widely known that aggregate output and consumption data are nonstationary, whereas first differences of these variables are not. We employ a wide range of panel unit root tests to check the statistical features of output and consumption series in our database. The results indicate that the $(\log )$ level of income and consumption series are nonstationary, but their first (log) differences are stationary. ${ }^{7}$ Hence, we follow the previous literature and carry out the analysis using first differenced series.

An ideal dataset to evaluate the impact of financial integration on the sensitivity of consumption to income changes should include direct measures of the effectiveness of restrictions on the capital account. Unfortunately, the available measures of restrictions on the capital account are much cruder for the broad set of countries in our sample. To maximize the information from available datasets, we use an array of rule-based (de jure) measures of financial integration. We also check the robustness of our findings by controlling for outcome-based (de facto) measures.

Our database includes multiple de jure measures of financial integration that are based on the information drawn from the International Monetary Fund's Exchange Restrictions and Exchange Arrangements (AREAER). The data series are mainly coded as a series of binary variables capturing whether a country has any restriction on its external (current and financial) accounts. A zero (0) indicates that there are restrictions in place and a one (1) suggests that the country is fully liberalized. The data distinguishes between the existence of multiple exchange rate practices, restrictions on the capital account, the current account or the ability to repatriate proceeds from exports. The original data does not distinguish between restrictions on inflows and outflows, and is available for the period 1966-2011.

We focus on two de jure measures of financial integration for our baseline results. Our first measure, based on the work by Chinn and Ito (2006), tracks the first standardized principle component

\footnotetext{
${ }^{6}$ The sample length is dictated by data availability. Most measures of financial integration are available only up to 2011: (i) IMF AREAER indicators are available for the 1966-2011 period; (ii) Quinn openness indicator is available for 1940-2011; (iii) Data series from Lane and Milesi-Ferretti and Chinn-Ito are available for the 1970-2011 period.

${ }^{7}$ We employ the tests offered by Levin, Lin and Chu (2002), Im, Pesaran and Shin (2003), and Hadri (2000). They all point to the same conclusions. The results of these tests are available upon request.
} 
of the major categories in the AREAER tables, including current account restrictions, export proceeds surrender requirements, the presence of multiple exchange rates, and the five-year rolling average of the IMF binary capital account restrictions. When each indicator is crudely measured (as is the case with the binary indicators of the AREAER), the first principal component provides an intuitively appealing composite measure (Quinn, Schindler and Toyoda, 2011). This measure is available for 182 countries for the period 1970-2011.

Our second de jure measure, initially put together by Quinn (1997), relies on indicators of capital account regulations based on a coding of the AREAER texts. This is also a composite index assigning equal weights to six categories: payments for imports; receipts from exports; payments for invisibles; receipts from invisibles; capital flows by residents; and capital flows by nonresidents. The Quinn index covers 90 countries over the period 1960-2011. We use these two measures in our regressions since they offer higher degrees of intensity and finer gradation for a large number of countries over an extended time period. We normalize the measures so each ranges between zero and one, where zero suggests restrictions on the capital account and 1 indicates that the capital account is fully liberalized.

We present the temporal evolutions of these measures of financial integration in Figure 1. Irrespective of the measure, the degree of financial integration has been increasing over time for the full sample. The increase has been fueled by a series of trade and financial liberalization initiatives around the world since the mid-1980s. Only about 15 percent of the countries in our sample had fully open capital accounts in 1984 compared to more than 50 percent in late 2000s.

This trend is largely driven by the group of developing economies as they have increasingly become more integrated to the global economy during the last two decades. Almost all of the advanced countries have now open capital accounts as implied by the de jure measures whereas a number of developing countries still maintain relatively closed capital accounts. In the case of the Chinn-Ito indicators, the average degree of financial integration for developing countries peaked at 0.5 in 2008, compared to 0.96 for advanced economies. For example, the Chinn-Ito indicator suggests that for Denmark, France and Norway, the degree of financial integration increased from 0.4 in the early 1970s to 1 (fully open) starting in early 1990s. The same indicator suggests that, for Colombia, the degree of financial integration increased from 0 (completely closed) in the late 1980s to 0.4 starting in 2004. For Brazil, the Chinn-Ito indicator suggests that the degree of financial integration was 0 (completely closed) until 1997 but reached 0.53 in 2006.

Our database also includes world and country-specific interest rates. For the world interest rate, we use the dollar London Interbank Offer Rate (LIBOR) rate. The real rate is adjusted for US inflation using the consumption price index from the Penn World Tables (PWT 8.1). For the country-specific real interest rates, we use the LIBOR rate adjusted by the country-specific consumption price indices in PWT 8.1.

\subsection{Basic Econometric Framework}

We follow the large literature that has tested various implications of the consumption Euler equation. We start with the basic consumption-saving decision of a representative agent whether to consume today or invest in a risk-free asset. The representative agent maximizes utility function $u\left(C_{t}^{j}\right)$, where $j$ indexes the countries, $j=1, \ldots, J$ and $C_{t}^{j}$ denotes aggregate consumption at time $t$. As usual, we also assume that countries have access to risk-free international bond markets, where 
the world real rate of return on the risk-free bond is defined as $R_{t}^{w}$. The optimization problem then implies the standard Euler equation:

$$
E_{t}\left[R_{t}^{w} \rho^{j} \frac{u^{\prime}\left(C_{t+1}^{j}\right)}{u^{\prime}\left(C_{t}^{j}\right)}\right]=1
$$

where $\rho^{j}$ is the discount rate for country $j$.

Assuming consumption growth is log-normally distributed and conditionally homoscedastic, the utility is iso-elastic, $u\left(C_{t}^{j}\right)=\frac{C_{t}^{j(1-\gamma)}}{(1-\gamma)} \cdot \gamma$ denotes the coefficient of relative risk aversion. Substituting actual for expected consumption growth, the Euler equation can be estimated in a standard form such as the regression:

$$
\Delta c_{t+1}^{j}=\theta_{0}^{j}+\theta_{1} r_{t}^{w}+\epsilon_{t+1}^{j}
$$

where lowercase letters represent the logarithm of the variables, $\theta_{0}^{j}$ is a constant representing a fixed country effect, $\theta_{1}=\frac{1}{\gamma}$, and $\epsilon_{t+1}^{j}=\Delta c_{t+1}^{j}-E_{t} \Delta c_{t+1}^{j}$.

In the Campbell and Mankiw setup, there are two groups of agents. The agents in the first group can borrow freely at market interest rates, implying that they behave exactly as in the equation above. The agents in the second group cannot borrow or lend and are called rule-of-thumb agents. They consume all of their income implying that their consumption follows the following process:

$$
\Delta c_{t+1}^{R O T, j}=\Delta y_{t+1}^{j}
$$

where the superscript "ROT" denotes rule-of-thumb agents and $y_{t+1}^{j}$ is the logarithm of income for country $j$ at time $t .{ }^{8}$ Campbell and Mankiw assume that the proportion of rule-of-thumb agents is constant and equal to $\beta$. Summing across all agents in the economy to obtain aggregate consumption implies a share-weighted average:

$$
\Delta c_{t+1}^{j}=(1-\beta)\left[\theta_{0}^{j}+\theta_{1} r_{t}^{w}\right]+\beta \Delta y_{t+1}^{j}+(1-\beta) \epsilon_{t+1}^{j}
$$

where $\beta$ the proportion of rule-of-thumb agents. We extend this basic empirical framework in Section 4 to take into account the role of financial integration and other country-specific features.

\section{Evolution of the Sensitivity of Consumption to Income over Time}

If financial integration helps reduce the sensitivity of consumption to income, one would expect a temporal decline in the correlation of consumption growth and income growth given the rapid increase in the degree of financial integration we have documented in the previous section. Using the regression framework in (4), we first analyze the evolution of the correlation of consumption growth to income growth over the period 1960-2011 and across different groups of countries. We simply trace the evolution of $\beta$ in order to evaluate the changes in the sensitivity of consumption to income.

\footnotetext{
${ }^{8}$ The implicit assumption here is that income growth for both ROT and non-ROT agents follows the same stochastic process.
} 
In order to fully utilize the cross-section and panel dimensions of the database, we employ two approaches. First, we focus on the cross-section and estimate (4) for each year over the full sample period. Because of the short sample size, the estimates of $\beta$ fluctuate from year to year. We track the estimates over time but, in order to convey the time-trend, we also smooth them by computing their average over a 12-year rolling window. ${ }^{9}$ Second, we estimate the same regression using 12 year rolling panels. This permits us to exploit both the time series and cross-sectional information available in the data. We control for time and country fixed effects in our panel regressions.

We display our findings in Table 1 and Figure 2. There are three major observations. First, our panel estimates for the full sample suggest that the sensitivity of consumption to income is about 0.76 for advanced economies and 0.81 for developing ones. Both cross-section and panel regressions show that there has been a significant decline in the sensitivity of consumption to income from the 1960s to the 2000s. If one accepts the interpretation by Campbell and Mankiw (1989), our panel regressions indicate that the proportion of rule-of-thumb agents declined from 0.88 to 0.68 in the case of advanced economies and from 0.88 to 0.76 in developing countries.

The earlier literature emphasizes that these coefficients are statistically different from zero and establishes the existence of rule-of-thumb agents but it offers little systematic guidance to what should be the parameter for the proportion of rule-of-thumb agents in calibrated open economy dynamic general equilibrium models. A number of studies consider the behavior of rule-of-thumb agents in different types of dynamic general equilibrium models to address a variety of questions. ${ }^{10}$ The inclusion of these types of agents improves the fit of some of these models and the results are sometimes quantitatively sensitive to the parameter of the rule-of-thumb agents.

Surprisingly, almost all of these studies follow the Campbell and Mankiw work (and other studies on the U.S. economy) and simply use a parameter of 0.5 as the proportion of rule-of-thumb agents in their baseline calibrations. Our results also suggest that the proportion is about 0.5 for the United States, but it tends to be much higher for a broader set of advanced countries and even higher for developing economies. ${ }^{11}$ Our study is the first one to provide a set of comparable statistics for the proportion of rule-of-thumb agents based on a large sample of countries, including advanced and developing countries over a long period of time.

Second, both cross-sectional and panel estimations indicate that there has been a trend decline in the sensitivity of consumption to income (Figure 2). There has been a slight increase in the last few years, possibly as a consequence of the global financial crisis. Third, the sub-groups of advanced and developing economies have both experienced a decline in the sensitivity of consumption to income over time but the extent of the decline has been larger in advanced economies than that of developing ones.

\footnotetext{
${ }^{9}$ This type of smoothing approach has also been used by some earlier studies to document the evolution of risk sharing (Obstfeld, 1994; Sorensen, Wu, Yosha and Zhu, 2007; Kose, Prasad and Terrones, 2009).

${ }^{10}$ For example, in the context of closed economy models, many authors have argued that a rule-of-thumb model of consumption behavior may be more suitable to study short-run effects of fiscal policies (Gali, Lopez-Salido and Valles, 2007) and monetary policies (Bilbiie, 2008). In the context of open economy models, Gao, Hnatkovska and Marmer (2014), and Kollmann $(2012,2015)$ analyze the role of rule-of-thumb agents to study various issues, including the consumption-real exchange rate anomaly, transmission of international business cycle, and the quantitative effects of fiscal shocks on the current account.

${ }^{11}$ Weber (2002) reports that a significant number of studies find that the parameter is between 0.3-0.6 percent for the U.S. economy. Asdrubali and Kim (2008) report that the coefficient is about 0.6-0.7 for the OECD counties.
} 


\section{Financial Integration and the Sensitivity of Consumption to In- come}

\subsection{Estimation Approach}

The results in the previous section suggest that the sensitivity of consumption to income is a timevarying function of the degree of financial integration. For simplicity, we assume that it varies linearly with the degree of financial integration:

$$
\beta_{t}^{j}=\beta_{0}-\beta_{1} \tau_{t}^{j}
$$

where, $0 \leq \tau_{t}^{j} \leq 1$, represents the degree of financial integration for country $j$. Substituting equation (5) into equation (4), we arrive at:

$$
\Delta c_{t+1}^{j}=\delta_{o}^{j}+\delta_{1}^{j} \tau_{t}^{j}+\left(\delta_{2}^{j}+\delta_{3}^{j} \tau_{t}^{j}\right) r_{t}^{w}+\left(\beta_{0}-\beta_{1} \tau_{t}^{j}\right) \Delta y_{t+1}^{j}+\varepsilon_{t+1}^{j}
$$

where, $\delta_{o}^{j}=\theta_{o}^{j}\left(1-\beta_{0}\right) ; \delta_{1}^{j}=\theta_{o}^{j} \beta_{1} ; \delta_{2}^{j}=\theta_{1}\left(1-\beta_{0}\right) ; \delta_{3}^{j}=\theta_{1} \beta_{1} ;$ and $\varepsilon_{t+1}^{j}=\left(1-\beta_{0}+\beta_{1} \tau_{t}^{j}\right) \epsilon_{t+1}^{j}$

Equation (6) suggests that the sensitivity of consumption to income varies across countries and across time based on the degree of financial integration. Following the standard codification of the indicators of financial integration, where $\tau_{t}^{j}=1$ suggests no restrictions on the capital account, we should expect a lower correlation between output and consumption growth for more financially integrated countries. ${ }^{12}$ In other words, we expect $\beta_{1}>0$. When $\tau_{t}^{j}=1$, the sensitivity of consumption to income would be $\left(\beta_{0}-\beta_{1}\right)$ for a fully financially integrated economy, and also depend on other structural factors as discussed in Section 5 . When $\tau_{t}^{j}=0$, we go back to the original set up in (4).

The estimation of (6) brings up various econometric challenges. For example, if income is non-stationary and income growth exhibits positive serial correlation - as supported by aggregate data - the error term would predict future income, and will be correlated with contemporaneous growth in current income in equation (6). This implies that consumption growth may be correlated with the error term. Therefore, the OLS would yield biased estimates as it would not control for endogeneity. Related to this, if the income process is a random walk, ex-post consumption growth will appear to co-move with ex-post income growth for both types of agents. In other words, $\beta$ would be unidentified if there exist no valid instruments for income growth.

However, the literature has been able to identify valid instruments for income growth, which may follow a more general process (Campbell and Mankiw 1989, 1991; Asdrubali and Kim, 2008). To obtain consistent estimates, the previous literature has employed instrumental variables. Lags of income and consumption growth rates are valid instruments (known to be correlated with current consumption and income growth) that also address the endogeneity between consumption and income. In addition, Campbell and Mankiw $(1989,1991)$ use lagged saving as an instrument and show that it increases the precision of the $\beta$ estimate.

\footnotetext{
${ }^{12}$ Our estimation approach presents a more a comprehensive framework than the one proposed by Lewis (1997) as she considers a specification that features a regression of the growth of consumption on output growth using a sample of countries with and without restrictions on their capital accounts and binary measures of integration. Our framework allows us to check how the relationship between financial integration and the sensitivity of consumption to income using continuous measures of integration. We check the robustness of our findings using the approach Lewis employed and types of binary measures in her sample.
} 
We follow the earlier literature and employ a dynamic panel framework using Arellano-Bond System GMM estimation. ${ }^{13}$ We include as controls lags 2-4 of consumption growth and income growth, and lagged saving (the difference between income and consumption). We also experiment with different lag structures to ensure that our estimates are robust. ${ }^{14}$

\subsection{Results}

We estimate equation (6) using the Chinn-Ito and Quinn measures of financial integration for 88 countries over the period 1960-2011. The results for all countries in the upper panel of Table 2 show that $\beta_{1}<0$. The coefficient on the financial integration variable is always negative and statistically significant. This indicates that a higher degree of financial integration is associated with lower correlation between consumption and income. ${ }^{15}$

We also examine the impact of real interest rates on the relationship between financial integration and the sensitivity of consumption to income in columns [3]-[6] in Table 1. ${ }^{16}$ We first assume that all countries face the same world interest rate in columns [3]-[4]. We then separately control for country-specific real interest rates in columns [5]-[6]. In all specifications, the interaction coefficient $\beta_{1}$ is negative and statistically significant again implying that in more financially integrated economies the sensitivity of consumption to income changes is lower. The coefficient for the interest rate is close to zero consistent with previous studies (Lewis, 1997).

The middle and lower panels of Table 1 present the estimation results for the groups of advanced and developing economies. The headline results hold for both groups and suggest a more robust negative link between financial integration and the sensitivity of consumption to income in advanced countries than developing ones. In the case of advanced economies which are more financially integrated, all specifications except one lead to negative and statistically significant coefficients. In the case of less financially integrated developing economies, the results are similar in the sense that the interaction coefficient is negative in all specifications and it is statistically significant in half of them. When we include interest rates in our regressions, our headline findings do not change. These results further support the hypothesis that a higher degree of financial integration is associated with a lower sensitivity of consumption to income. ${ }^{17}$

\footnotetext{
${ }^{13}$ Many other papers in the literature also use the GMM estimation and employ the same set of instruments we have here (Asdrubali and Kim, 2008; Caroll, Slacalek and Sommer, 2011). Lewis (1997) uses lags of consumption and income growth as instruments in her regressions.

${ }^{14}$ Note that the error term in equation (6), which is the unexpected change in income of the set of agents that are not rule-of-thumb, would have an increasing variance as population grows, even in the case when the proportion of current income agents remains fixed, likely exacerbating measurement error. While this measurement error may contribute to the high sensitivity of consumption to income changes (see Lewis, 1997), there is no apparent reason why the measurement error would contribute to a lower sensitivity of consumption to income in more financially open economies.

${ }^{15}$ According to the Campbell and Mankiw interpretation, the proportion of rule-of-thumb agents tends to be lower in countries with a higher degree of international financial integration. We assume an $M A(2)$ process for the error term as in Lewis (1997). The results are similar for lags 2-6. We also experimented with lags 3-5 and the results are again supportive of financial openness being associated with a lower sensitivity of consumption to income. The coefficients for $\beta_{0}$ (the correlation between consumption and income growth) are quantitatively similar to those reported in previous studies using similar regressions (Lewis, 1996, 1997; Fratzscher and Imbs, 2009).

${ }^{16}$ Since the ex-post interest rate is not known at time $t$, we follow Lewis (1997) and use as instruments lagged values of the real interest rate in addition to lags of consumption growth, income growth and saving.

${ }^{17}$ We also examine how our results change under different empirical specifications. For example, we employ a specification like the one in Lewis (1997) and simply regress the growth of consumption on growth of output using
} 


\subsection{Robustness Exercises}

We analyze the robustness of our findings by employing a wide range of additional controls. We start with some binary measures of financial and trade integration in our regressions. Specifically, we use various measures of restrictions on the capital account and export proceeds, and indicators of equity market and trade liberalization. ${ }^{18}$ The findings support our headline results that a higher degree of integration is associated with a lower sensitivity of consumption to income changes.

In addition, we check the robustness of our findings using de facto measures of financial integration for the full sample and sub-samples of countries (Lane and Milesi-Ferretti, 2007). We control for a wide range of outcome-based measures of financial integration: total stock of inflows (liabilities) and outflows (assets), foreign direct investment, equity, and debt flows. Our headline result is robust for all measures of de facto integration: the integration coefficient is significantly negative suggesting that, even after controlling for de facto measures, a higher degree of financial integration tends to be associated with a lower sensitivity of consumption to income (Table A3 in the Appendix). To deal with the endogeneity issues inherent in these types of de facto measures and to estimate their effects on the sensitivity of consumption to income changes, one may need a more structural approach as in Davis (2014).

The findings are also robust to controlling for measures of de facto trade integration and financial sector development. We consider the standard de facto measure of trade integration: the sum of exports and imports relative to output. The results are consistent with our baseline findings: financial integration tends to have a negative impact on the sensitivity of consumption to income even after controlling for trade integration and financial sector development (Table A4 in the Appendix).

\section{Discussion: Alternative Interpretations of Changes in the Sen- sitivity of Consumption to Income ${ }^{19}$}

We focus on the potential role of financial integration in explaining the temporal variations in the sensitivity of consumption to income fluctuations. There are other possible structural drivers of these temporal changes that could arise in a reduced-form framework, even if the intertemporal consumption Euler equation holds. In this section, we briefly discuss three of these explanations and their implications for our exercise: an increase in the persistence of shocks to income; an increase in the cross-country correlations of income shocks; and the convergence of interest rates. We then provide a short discussion of different interpretations of the dependence of consumption to income.

Changes in the persistence of income shocks over time: The sensitivity of consumption to income fluctuations also depends on the persistence of income shocks. A decline in the persistence

a sample of countries with and without restrictions on their capital accounts. We then test whether the coefficients differ across two sub-samples. The results do not change in the sense that the coefficient associated with the sample of restricted countries is statistically significantly greater than the one associated with the unrestricted one (Table A1 in the Appendix).

${ }^{18}$ We show detailed results for these robustness exercises in Table A2 of the Appendix. We also confirm that the headline results are robust to changes in time periods, including the period 1994-2011 (the globalization period) and alternative cut-off dates for the globalization period (Table A5).

${ }^{19}$ We thank Mario Crucini and an anonymous referee for providing detailed feedback on the alternative interpretations we present in this section. 
of income shocks may lower the volatility of consumption as agents would be less likely to adjust their consumption in response to such shocks. If the persistence of the income shocks decreases around the time when the elasticity of consumption to income declines, the results could then be attributed to agents' optimal response to this drop in the persistence, and not necessarily to an increase in the degree of financial integration.

To check the role of the persistence of the income shocks, we analyze how the persistence of income shocks evolve over time using Total Factor Productivity (TFP) data from PWT 8.1. Specifically, we study the evolution of the median AR(1) coefficient of the changes in TFP for each country group. For the full sample, as well as for the advanced and developing country sub-groups, the median persistence has increased slightly until the late 1980s (from near zero in the late 1970s to close to 0.2 in late $1980 \mathrm{~s}$, but has not changed much since then). This would suggest that the decline in the sensitivity of consumption to income changes could not have been associated with the changes in the persistence of income shocks (Figure A1 in the Appendix).

The sensitivity of consumption to income can also be affected by the correlation between the permanent and transitory components of expected shocks to income (Deaton, 1987; Quah, 1991). The sensitivity of consumption to income would be lower if the correlation between the permanent and transitory shocks is negative. A decomposition of permanent and transitory components would require detailed information on expected income but it is not possible with the aggregate data we have here. However, this remains an interesting avenue for future research.

Changes in the correlation of income shocks: The elasticity of consumption to income also depends on the cross-country correlations of income shocks. On the one hand, if income shocks are highly correlated, this would lower incentives to share risk ex-ante with the rest of the world and may increase the sensitivity of consumption to domestic income. On the other hand, if highly correlated cross-country income shocks are due to a decline in global uncertainty, this can facilitate cross-border borrowing and lending, and, in turn, lead to a lower sensitivity of consumption to income. We analyze the evolution of the cross-country correlation of TFP shocks. Our findings indicate that the average cross-country TFP correlations have been essentially flat for most of the period (Figure A2 in the Appendix). Given the absence of a trend in the evolution of TFP correlations, it is unlikely that the sensitivity of consumption to income has declined because of changes in these correlations.

Convergence of interest rates: The sensitivity of consumption to income can be lower because of the convergence of interest rates over time. In an economy with participation constraints, only some agents can borrow and lend at the world interest rate, which tends to be lower than the domestic interest rate. As the economy becomes more financially integrated, more agents are able to access international financial markets and undertake transactions at the world interest rate. As the degree of financial integration increases globally, national interest rates tend to converge to the world rate, making countries subject to similar interest rate shocks. Assuming the world interest rate is less volatile than national interest rates, this would imply lower volatility of consumption growth and higher cross-country correlations of consumption. A lower interest rate and less volatile consumption growth would decrease savings and increase borrowing at the margin. As a result, the degree of co-movement of consumption with domestic income would decrease, making it harder to disentangle the impact of interest rates from that of financial integration on the sensitivity of consumption to income in a regression framework like the one we presented earlier.

However, observed interest rates might not fully reflect the degree of financial integration of an economy as they are affected by many other factors, including country risk premia, and monetary 
and fiscal policies. Moreover, some agents might not be able to obtain credit at the world interest rates. Following the earlier literature, we control for both international and domestic interest rates in our regressions. The results suggest a strong association between financial integration and the sensitivity of consumption to income, even after controlling for these interest rates.

Other studies consider the deeper shortcomings of the theory as possible explanations of the dependence of consumption to income. For example, one interpretation treats the violation of the $\mathrm{PIH}$, i.e., the positive correlation between expected consumption and expected income growth, as evidence against intertemporal consumption smoothing (Lewis, 1997; Asdrubali and Kim, 2008). This interpretation is derived directly from the Campbell-Mankiw framework and views the sensitivity of consumption to income as the proportion of "liquidity-constrained" agents who consume their current income and cannot smooth income shocks inter-temporally. Financial integration would facilitate borrowing and lending and help lower the proportion of liquidity constrained agents. Some studies indeed report that the degree of inter-temporal consumption smoothing across countries is much lower than the one within countries, and suggest that financial constraints across countries may explain the discrepancy (Ostergaard, Sorensen and Yosha, 2002; Asdrubali and Kim, 2008). ${ }^{20}$

However, there are at least three problems with this interpretation. First, liquidity constrained agents may smooth consumption inter-temporally through their savings, social arrangements and government transfers. Second, there is no guarantee that the proportion of rule-of-thumb agents is constant over time as we document in Section 3. Third, even if one accepts the existence of liquidity constraints, as we discuss below, the estimated elasticity of consumption to income changes is a function of the persistence and cross-country correlations of underlying output and productivity shocks. Consequently, the structural elasticity of consumption to liquidity constraints remains unobserved and could be lower than that implied by the reduced-form estimations we present here.

The sensitivity of consumption to income fluctuations would also be lower if agents decide to share risk ex-ante by pooling part of their income in international financial markets (Crucini, 1999). This assumes that agents can insure part of their consumption ex-ante, before any shocks occur, while still being able to borrow and lend ex-post. A few authors study the extent of risk-sharing in regions within countries or a small group of advanced economies, allowing for the possibility of (incomplete) ex-ante risk sharing and focus on its precise measurement (Obstfeld, 1994; Crucini, 1999; Crucini and Hess, 2000). Crucini (1999) estimates a model of incomplete risk-sharing across locations within countries and across countries and finds that the extent of risk sharing across countries is lower compared to the one within countries. We estimate an incomplete risk-pooling model similar to the one in Crucini (1999) and check the evolution of the sensitivity of consumption to income changes over 12-year rolling panels, while controlling for fluctuations in aggregate consumption growth (Figure A3 in the Appendix). The results are similar to our headline findings in Figure 2.

\section{Conclusions}

We have conducted a comprehensive empirical analysis of the relationship between financial integration and the sensitivity of consumption to income. In particular, we studied the relationship using a rich database that covers a large number of countries over a long time period and includes a wide range of measures of financial integration. This allowed us to examine how the relationship

\footnotetext{
${ }^{20}$ The sensitivity of consumption to income may also depend on the nature of productivity shocks even when asset markets are incomplete (Baxter and Crucini, 1995).
} 
has changed over time and across countries. Our results indicate that, consistent with theoretical predictions, a higher degree of financial integration is associated with a lower sensitivity of consumption to income over time. We also provide a discussion of several alternative interpretations of changes in the sensitivity of consumption and income over time.

These results point to two areas for future research. First, country-specific features can affect the relationship between international financial integration and the sensitivity of consumption to income. For example, our simple robustness analysis suggests that trade integration and financial sector development can affect this relationship. It would be useful to conduct a comprehensive study of the linkages between financial integration and trade and financial development, and how these linkages endogenously affect the proportion of rule-of-thumb agents in an economy, using a framework similar to Davis (2014). Second, it would be useful to study how the changes in the sensitivity of consumption to income affect the transmission of international business cycles using the benchmark statistics we provide here.

\section{References}

[1] Asdrubali, P. and S. Kim. 2008. "Incomplete Intertemporal Consumption Smoothing and Incomplete Risk Sharing." Journal of Money, Credit and Banking 40(7), 1521-1531.

[2] Baxter, M. and M. J. Crucini. 1995. "Business Cycles and the Asset Structure of Foreign Trade." International Economic Review, November, Vol. 36, No. 4, 821-854.

[3] Bilbiie, F.O., 2008. "Limited asset markets participation, monetary policy and (inverted) aggregate demand logic." J. Econ. Theory 140 (May (1)), 162-196

[4] Campbell, J. Y. and N. G. Mankiw. 1989. "International evidence on the persistence of economic fluctuations," Journal of Monetary Economics, Elsevier, vol. 23(2), pages 319-333, March.

[5] Campbell, J. Y. and N. G. Mankiw. 1991. "Permanent Income, Current Income, and Consumption," NBER Working Papers 2436, National Bureau of Economic Research, Inc.

[6] Carroll, C. D., J. Slacalek, and M. Sommer. 2011. "International evidence on sticky consumption growth." The Review of Economics and Statistics 93 (4), 1135-1145.

[7] Chinn, M. D. and H. Ito, 2006. "What Matters for Financial Decelopment? Capital Controls, Institutions, and Interactions," Journal of Development Economics, Volume 81, Issue 1, Pages 163-192 (October).

[8] Cochrane, J. 1991. "A Simple Test of Consumption Insurance." Journal of Political Economy 99:5 (October 1991) 957-976.

[9] Crucini, M. J., 1999. "On International and National Dimensions of Risk Sharing." The Review of Economics and Statistics, February, Vol. LXXXI, No. 1, 73-84.

[10] Crucini, M. J. and G. D. Hess. 2000. "International and Intranational Risk Sharing," in Intranational Macroeconomics, Gregory D. Hess and Eric van Wincoop, editors, Cambridge, U.K.: Cambridge University Press, 2000, 37-59. 
[11] Davis, S. 2014. "Financial Integration and International Business Cycle Co-movement.", Journal of Monetary Economics, 64, 99-111.

[12] Deaton, A. 1987. "Life-Cycle Models of Consumption: Is the Evidence Consistent with the Theory?" In Advances in Econometrics: Fifth World Congress, Vol. 2. Edited by Truman F. Bewley. New York: Cambridge University Press, 1987.

[13] Fratzscher M. and J. Imbs J. 2009 "Risk sharing, finance and institutions in international portfolio." J Financial Econ 94:428-447

[14] Galí, J., Lopez-Salido, J. D. and J. Valles, 2007 "Understanding the Effects of Government Spending on Consumption" Journal of the European Economic Association 5, 227-250.

[15] Gao, X., Hnatkovska, V., and V. Marmer. 2014. "Limited Participation in International Business Cycles Models: A Formal Evaluation." Journal of Economic Dynamics and Control 39, $255-272$.

[16] Hadri, K. 2000. "Testing for stationarity in heterogeneous panel data." Econometrics Journal 3: $148-161$

[17] Im, K. S., M. H. Pesaran, and Y. Shin. 2003. "Testing for unit roots in heterogeneous panels.", Journal of Econometrics 115: 53-74.

[18] Jappelli, T., and L. Pistaferri. 2010, The Consumption Response to Income Changes, Annual Review of Economics 2(1), 479-506.

[19] Kollmann, R. 2012. "Limited asset market participation and the consumption-real exchange rate anomaly", Canadian Journal of Economics, 45 (May (2)) (2012), pp. 566-584

[20] Kollmann, R. 2015. "Exchange Rates Dynamics with Long-Run Risk and Recursive Preferences." Open Economics Review, 26: 175-196.

[21] Kose, M. A., E. S. Prasad, and M. E. Terrones. 2009. "Does Financial globalization promote risk sharing?," Journal of Development Economics, Elsevier, vol. 89(2), pages 258-270, July.

[22] Lane, P. R. and G. M. Milesi-Ferretti. 2007. "The external wealth of nations mark II: Revised and extended estimates of foreign assets and liabilities, 1970-2004", Journal of International Economics 73, November, 223-250.

[23] Levin, A., C.-F. Lin, and C.-S. J. Chu. 2002. "Unit root tests in panel data: Asymptotic and finite-sample properties.", Journal of Econometrics 108: 1-24.

[24] Lewis, K. K., 1996. "What Can Explain the Apparent Lack of International Consumption Risk Sharing?" Journal of Political Economy, Vol. 104, No. 2, pp. 267-297.

[25] Lewis, K. K. 1997. "Are Countries with Official International Capital Restrictions Liquidity Constrained?", European Economic Review, 41, 1079 - 1109.

[26] Mace, B. "Full Insurance in the Presence of Aggregate Uncertainty." Journal of Political Economy 1991, 928-956.

[27] Mankiw, N.G., 2000. "The savers-spenders theory of fiscal policy." American Economic Review 90 (May (2)), 120-125. 
[28] Obstfeld, M. 1994, "Risk-taking, Global Diversification, and Growth," American Economic Review 84, 1310-29.

[29] Ostergaard, C., B. E. Sorensen, and O. Yosha. 2002. "Consumption and Aggregate Constraints: Evidence from US States and Canadian Provinces.", Journal of Political Economy, 110, 634-45.

[30] Quah, D. 1990. "Permanent and Transitory Movements in Labor Income: An Explanation for the "Excess Smoothness" in Consumption." Journal of Political Economy, June, 98:3, 449-475.

[31] Quinn, D., 1997, "The Correlates of Change in International Financial Regulation," American Political Science Review, Vol. 91, pp. 531-51.

[32] Quinn, D. P., M. Schindler, and A. M. Toyoda. 2011. "Assessing Measures of Financial Openness and Integration." IMF Economic Review. 59(3):488-522

[33] Sørensen, B. E., Y. Oved, Y. Wu, Z. Yu. 2007. "Home bias and international risk sharing: twin puzzles separated at birth." Journal of International Money and Finance 26 (4), 587-605.

[34] Weber, C.E., 2002. "Intertemporal non-separability and "rule-of-thumb" consumption." Journal of Monetary Economics, 49, 293-308. 


\section{Figure 1. Evolution of Financial Integration}

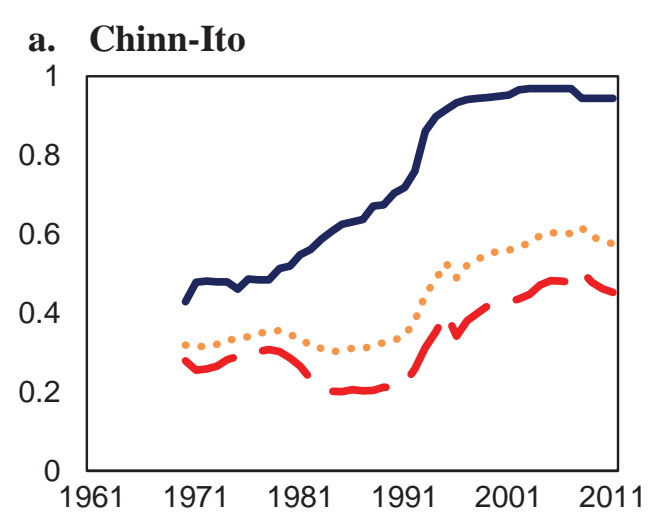

\section{b. Quinn}

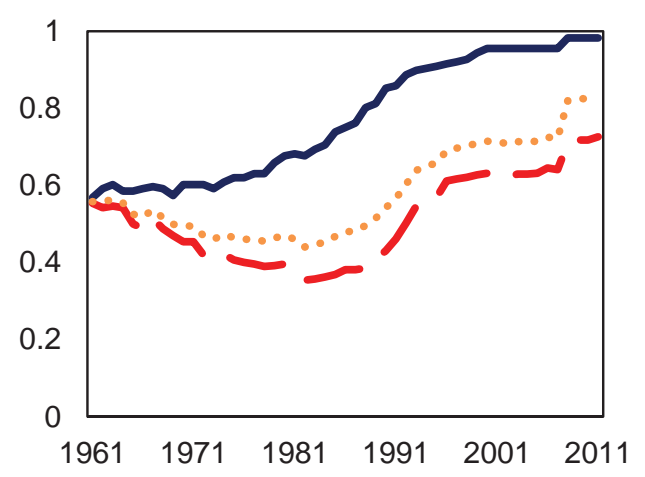

\section{...All Countries -Advanced Economies - Developing Economies}

Notes: The figures show country averages for each year. The solid (blue) lines show averages for Advanced Economies, the dashed (red) lines show averages for Developing Economies and the dotted (orange) lines show averages for all countries in our sample. The vertical axis shows restrictions in each of the respective categories. A zero (0) shows that there are restrictions in place and one (1) suggests that the country is liberalized. "Chinn-Ito" and "Quinn" refers to the Chinn-Ito and Quinn measure of financial integration, respectively. 
Figure 2. Evolution of the Sensitivity of Consumption to Income

\section{a. Cross-sectional - All Countries}

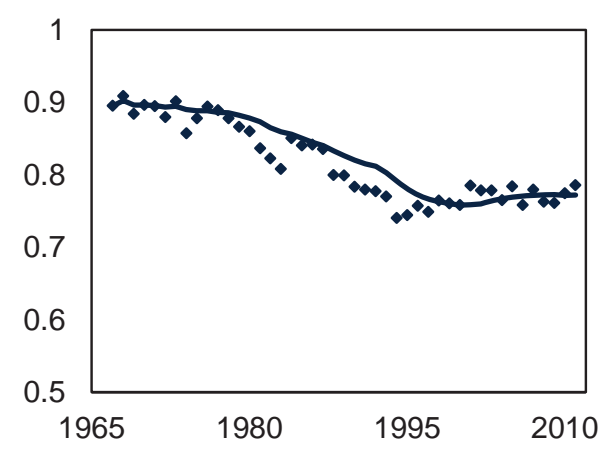

c. Cross-sectional - Advanced Economies

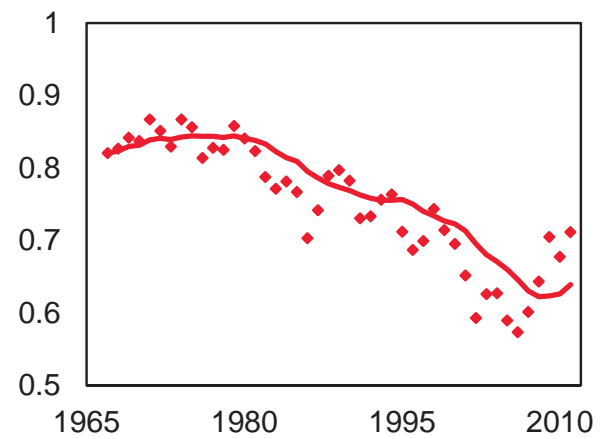

e. Cross-sectional - Developing Economies

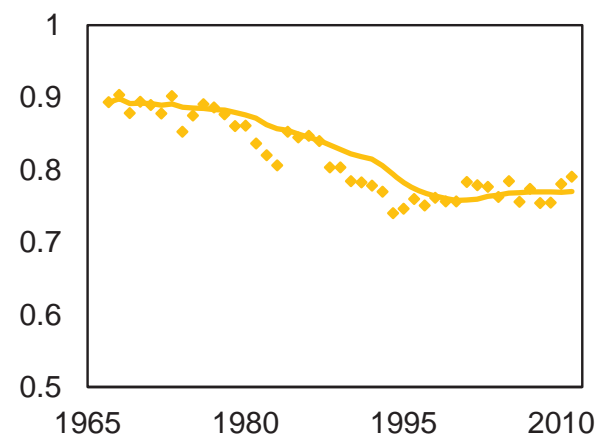

b. Panel - All Countries

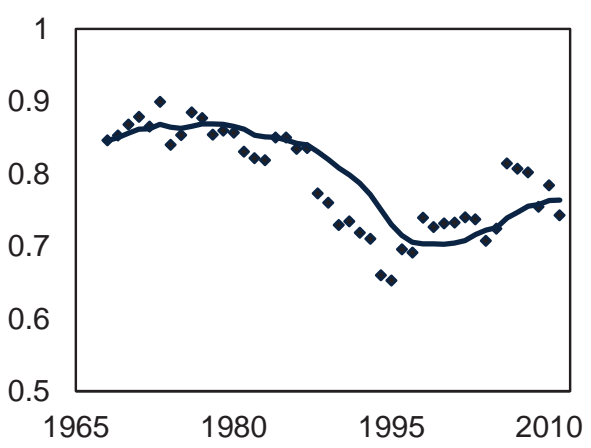

d. Panel - Advanced Economies

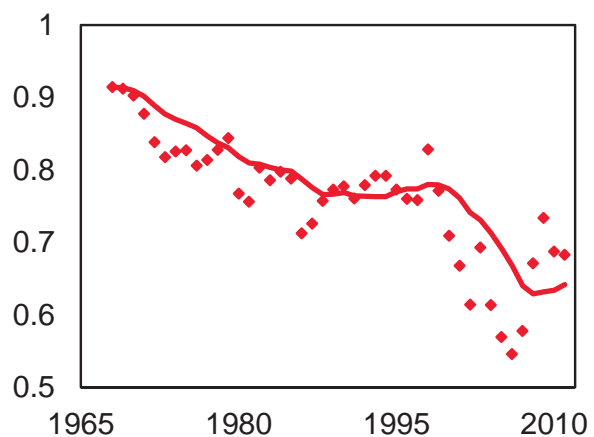

f. Panel - Developing Economies

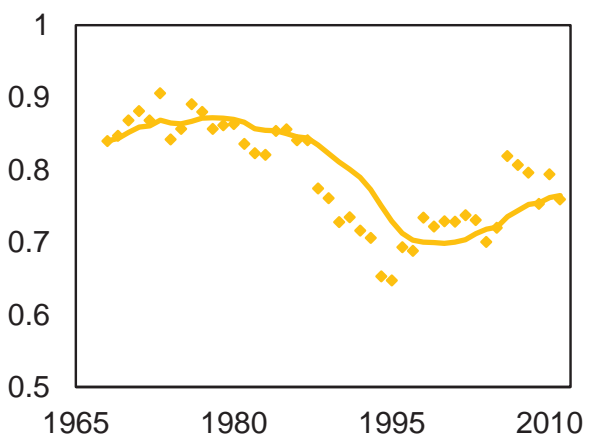

Notes: The figure shows the evolution of cross-section (left panel) and panel estimates (right panel) of regressing consumption growth on output growth. Sensitivity of consumption to income refers to the coefficient derived from a regression of consumption growth on output growth. The dots in the left panel show averages over a 12year rolling window. The dots in the right panel show coefficient estimates of 12-year rolling panels. The lines show the 9-year moving average trendlines. 
Table 1: Estimates of the Sensitivity of Consumption to Income

\begin{tabular}{ccc}
\hline All & Advanced & Developing \\
Countries & Economies & Economies \\
\hline
\end{tabular}

Panel Regressions

$\begin{array}{lcccc}\text { [1] } & 1960-2011 & 0.801 & 0.753 & 0.806 \\ & & & & \\ {[2]} & 1960-2011 & 0.795 & 0.758 & 0.796 \\ {[3]} & 1960-1971 & 0.879 & 0.877 & 0.881 \\ {[4]} & 2000-2011 & 0.743 & 0.683 & 0.759\end{array}$

\section{Cross-Section Regressions}

$\begin{array}{lllll}{[5]} & 1960-1971 & 0.895 & 0.867 & 0.890 \\ {[6]} & 2000-2011 & 0.786 & 0.711 & 0.791\end{array}$

Notes: These statistics refer to estimates derived from a regression of consumption growth on output growth. The coefficients are statistically significant at $1 \%$ level. Sensitivity of consumption to income refers to the coefficient estimated from a regression of consumption growth on income growth. Row [1] shows estimates derived from the GMM Dynamic Panel estimates using lags 2-4 of consumption and income growth and lagged saving as instruments. Rows [2]-[4] show panel OLS estimates using country and year fixed effects. Rows [5]-[6] show the average of the cross-sectional estimates for the respective period. 
Table 2: Financial Integration and the Sensitivity of Consumption to Income

\begin{tabular}{|c|c|c|c|c|c|c|}
\hline & $\begin{array}{c}\text { Chinn-Ito } \\
{[1]}\end{array}$ & $\begin{array}{l}\text { Quinn } \\
\text { [2] }\end{array}$ & $\begin{array}{c}\text { Chinn-Ito } \\
{[3]}\end{array}$ & $\begin{array}{l}\text { Quinn } \\
\text { [4] }\end{array}$ & $\begin{array}{c}\text { Chinn-Ito } \\
\text { [5] }\end{array}$ & $\begin{array}{l}\text { Quinn } \\
\text { [6] }\end{array}$ \\
\hline Output & $\begin{array}{c}0.899 \\
{[0.010]^{* * *}}\end{array}$ & $\begin{array}{c}0.987 \\
{[0.028]^{* * *}}\end{array}$ & $\begin{array}{c}0.869 \\
{[0.018]^{* * *}}\end{array}$ & $\begin{array}{c}1.063 \\
{[0.025]^{* * *}}\end{array}$ & $\begin{array}{c}0.862 \\
{[0.020]^{* * *}}\end{array}$ & $\begin{array}{c}0.981 \\
{[0.028]^{* * *}}\end{array}$ \\
\hline Output $\times$ De Jure & $\begin{array}{c}\mathbf{- 0 . 1 3 6} \\
{[0.010]^{* * *}}\end{array}$ & $\begin{array}{c}\mathbf{- 0 . 2 8 5} \\
{[0.045]^{* * *}}\end{array}$ & $\begin{array}{c}\mathbf{- 0 . 1 1 3} \\
{[0.026]^{* * *}}\end{array}$ & $\begin{array}{c}\mathbf{- 0 . 4 2 4} \\
{[0.035]^{* * *}}\end{array}$ & $\begin{array}{c}\mathbf{- 0 . 0 8 7} \\
{[0.028]^{* * *}}\end{array}$ & $\begin{array}{c}\mathbf{- 0 . 2 6 1} \\
{[0.044]^{* * *}}\end{array}$ \\
\hline $\begin{array}{l}\text { World Interest Rate } \times \\
\text { De Jure }\end{array}$ & & & $\begin{array}{c}0.018 \\
{[0.001]^{* * *}}\end{array}$ & $\begin{array}{c}0.015 \\
{[0.001]^{* * *}}\end{array}$ & & \\
\hline $\begin{array}{l}\text { Country Specific } \\
\text { Interest Rate } \times \text { De Jure }\end{array}$ & & & & & $\begin{array}{c}0.014 \\
{[0.001]^{* * *}}\end{array}$ & $\begin{array}{c}0.010 \\
{[0.002]^{* * *}}\end{array}$ \\
\hline $\begin{array}{l}\text { Observations } \\
\text { Countries }\end{array}$ & $\begin{array}{c}3,555 \\
88\end{array}$ & $\begin{array}{c}4,526 \\
85\end{array}$ & $\begin{array}{c}3,467 \\
88\end{array}$ & $\begin{array}{c}3,826 \\
85\end{array}$ & $\begin{array}{c}3,467 \\
88\end{array}$ & $\begin{array}{c}3,826 \\
85\end{array}$ \\
\hline
\end{tabular}

\section{$\underline{\text { Advanced Economies }}$}

\begin{tabular}{|c|c|c|c|c|c|c|}
\hline Output & $\begin{array}{c}1.121 \\
{[0.074]^{* * *}}\end{array}$ & $\begin{array}{c}1.045 \\
{[0.180]^{* * *}}\end{array}$ & $\begin{array}{c}1.099 \\
{[0.075]^{* * *}}\end{array}$ & $\begin{array}{c}0.969 \\
{[0.124]^{* * *}}\end{array}$ & $\begin{array}{c}1.067 \\
{[0.065]^{* * *}}\end{array}$ & $\begin{array}{c}0.939 \\
{[0.097]^{* * *}}\end{array}$ \\
\hline Output $\times$ De Jure & $\begin{array}{c}\mathbf{- 0 . 4 3 4} \\
{[0.088]^{* * *}}\end{array}$ & $\begin{array}{c}\mathbf{- 0 . 3 1 9} \\
{[0.168]^{*}}\end{array}$ & $\begin{array}{c}\mathbf{- 0 . 4 3 3} \\
{[0.131]^{* * *}}\end{array}$ & $\begin{array}{c}-0.284 \\
{[0.195]}\end{array}$ & $\begin{array}{c}\mathbf{- 0 . 3 8 3} \\
{[0.124]^{* * *}}\end{array}$ & $\begin{array}{c}\mathbf{- 0 . 2 5 2} \\
{[0.136]^{*}}\end{array}$ \\
\hline $\begin{array}{l}\text { World Interest Rate } \times \\
\text { De Jure }\end{array}$ & & & $\begin{array}{l}-0.009 \\
{[0.015]}\end{array}$ & $\begin{array}{c}0.024 \\
{[0.021]}\end{array}$ & & \\
\hline $\begin{array}{l}\text { Country Specific } \\
\text { Interest Rate } \times \text { De Jure }\end{array}$ & & & & & $\begin{array}{c}0.009 \\
{[0.022]}\end{array}$ & $\begin{array}{c}0.035 \\
{[0.021]^{*}}\end{array}$ \\
\hline $\begin{array}{l}\text { Observations } \\
\text { Countries }\end{array}$ & $\begin{array}{c}892 \\
22\end{array}$ & $\begin{array}{c}1,337 \\
22\end{array}$ & $\begin{array}{c}870 \\
22\end{array}$ & $\begin{array}{c}1,053 \\
22\end{array}$ & $\begin{array}{c}870 \\
22\end{array}$ & $\begin{array}{c}1,053 \\
22\end{array}$ \\
\hline
\end{tabular}

Developing Economies

\begin{tabular}{|c|c|c|c|c|c|c|}
\hline Output & $\begin{array}{c}0.887 \\
{[0.018]^{* * *}}\end{array}$ & $\begin{array}{c}0.945 \\
{[0.050]^{* * *}}\end{array}$ & $\begin{array}{c}0.847 \\
{[0.037]^{* * *}}\end{array}$ & $\begin{array}{c}1.004 \\
{[0.059]^{* * *}}\end{array}$ & $\begin{array}{c}0.815 \\
{[0.040]^{* * *}}\end{array}$ & $\begin{array}{c}0.886 \\
{[0.095]^{* * *}}\end{array}$ \\
\hline Output $\times$ De Jure & $\begin{array}{c}\mathbf{- 0 . 1 0 3} \\
{[0.026]^{* * *}}\end{array}$ & $\begin{array}{c}-\mathbf{0 . 2 1 7} \\
{[0.080]^{* * *}}\end{array}$ & $\begin{array}{l}-0.086 \\
{[0.056]}\end{array}$ & $\begin{array}{c}\mathbf{- 0 . 3 0 3} \\
{[0.102]^{* * *}}\end{array}$ & $\begin{array}{l}-0.055 \\
{[0.061]}\end{array}$ & $\begin{array}{l}-0.100 \\
{[0.161]}\end{array}$ \\
\hline $\begin{array}{l}\text { World Interest Rate } \times D e \\
\text { Jure }\end{array}$ & & & $\begin{array}{c}0.055 \\
{[0.004]^{* * *}}\end{array}$ & $\begin{array}{c}0.035 \\
{[0.006]^{* * *}}\end{array}$ & & \\
\hline $\begin{array}{l}\text { Country Specific Interest } \\
\text { Rate } \times \text { De Jure }\end{array}$ & & & & & $\begin{array}{c}0.024 \\
{[0.003]^{* * *}}\end{array}$ & $\begin{array}{c}0.014 \\
{[0.004]^{* * *}}\end{array}$ \\
\hline $\begin{array}{l}\text { Observations } \\
\text { Countries }\end{array}$ & $\begin{array}{c}2,663 \\
66\end{array}$ & $\begin{array}{c}3,189 \\
63\end{array}$ & $\begin{array}{c}2,597 \\
66\end{array}$ & $\begin{array}{c}2,773 \\
63\end{array}$ & $\begin{array}{c}2,597 \\
66\end{array}$ & $\begin{array}{c}2,773 \\
63\end{array}$ \\
\hline
\end{tabular}

Note: Dependent variable is consumption growth. GMM Dynamic Panel Estimates. Lags 2-4 of consumption growth, all right hand side variables and lagged saving are used as instruments. De Jure refers to financial integration measures of Chinn-Ito and Quinn. In columns [3]-[6], interest rate is also included as a control. Sample period 1960-2011 or as dictated by availability of data. 
Appendix:

Figure A1: Persistence of Productivity over time

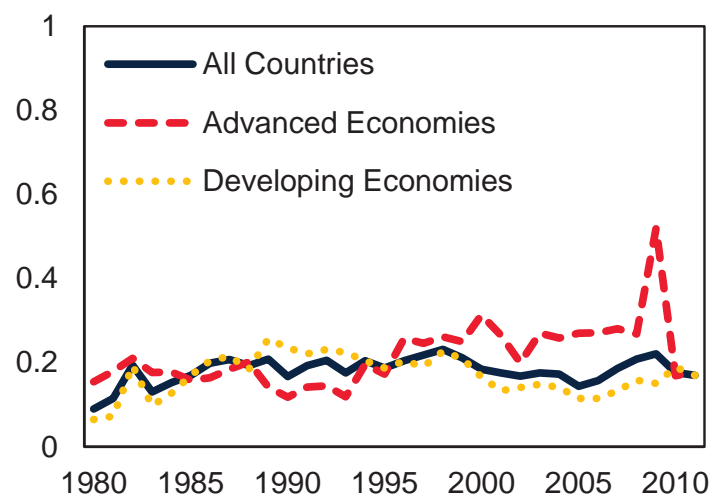

Figure A2: Cross-Country Productivity Correlations

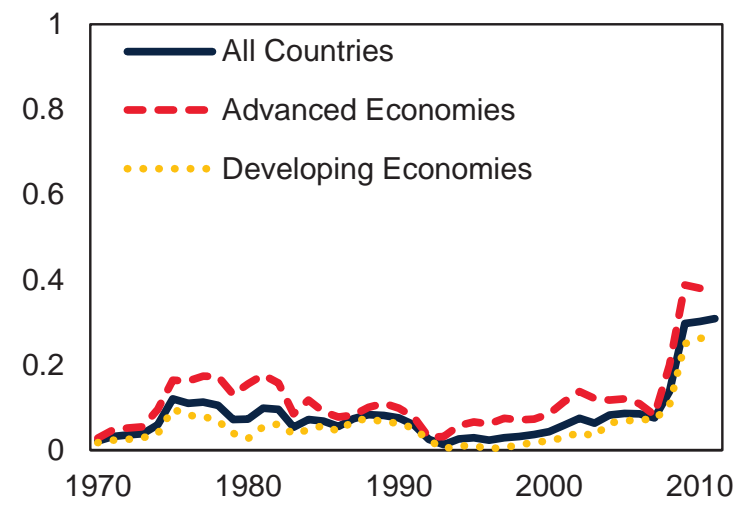

Figure A3: Evolution of Intertemporal Smoothing

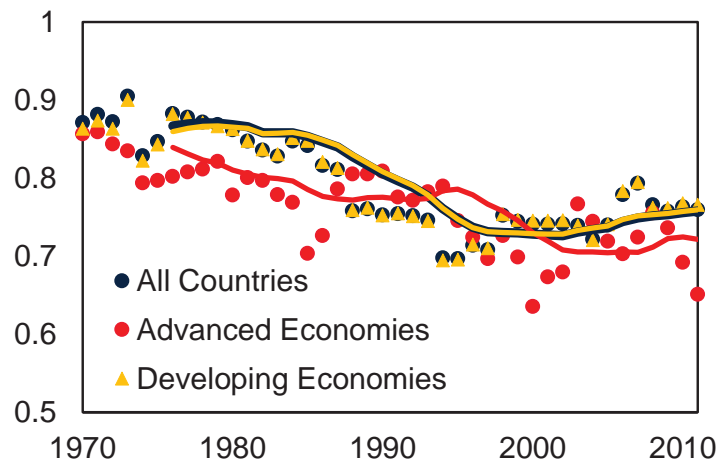

Notes:

A1: Median rolling AR(1) coefficient estimates of regressing TFP growth on its lag for each country group. The length of the rolling window is 20 years. Results are robust to various window lengths. 1960-2011.

A2: Productivity correlations refer to the average rolling 9-year bilateral correlations of productivity of each country with that of all the other countries in the sample. The results are robust to various window lengths, and are similar for weighted-averages when export shares and import shares are used as weights. 1960-2011.

A3: Inter-temporal smoothing refers to the estimated coefficients (dots) of 12-year rolling panel regressions of consumption growth on output growth for each country group. Aggregate consumption growth is also used as a control in the panel regressions. The lines show the 9-year moving average trendlines. 


\section{Table A1: Sensitivity of Consumption to Income for Open and Closed Economies}

\begin{tabular}{|c|c|c|c|c|}
\hline & $\begin{array}{c}\text { XR } \\
\text { Practices }\end{array}$ & $\begin{array}{l}\text { Current } \\
\text { Account }\end{array}$ & $\begin{array}{c}\text { Capital } \\
\text { Account }\end{array}$ & $\begin{array}{c}\text { Export } \\
\text { Proceeds }\end{array}$ \\
\hline & [1] & [2] & [3] & [4] \\
\hline Output $\times$ Open & $\begin{array}{c}\mathbf{0 . 7 0 7} \\
{[0.008]^{\star \star \star}}\end{array}$ & $\begin{array}{c}\mathbf{0 . 7 4 4} \\
{[0.011]^{\star \star \star}}\end{array}$ & $\begin{array}{c}\mathbf{0 . 7 7 3} \\
{[0.010]^{\star \star \star}}\end{array}$ & $\begin{array}{c}0.793 \\
{[0.008]^{\star \star \star}}\end{array}$ \\
\hline Output $\times$ Closed & $\begin{array}{c}1.064 \\
{[0.018]^{\star \star \star}}\end{array}$ & $\begin{array}{c}0.941 \\
{[0.012]^{\star \star \star}}\end{array}$ & $\begin{array}{c}\mathbf{0 . 8 8 7} \\
{[0.011]^{\star \star \star}}\end{array}$ & $\begin{array}{c}\mathbf{0 . 8 7 7} \\
{[0.007]^{\star \star \star}}\end{array}$ \\
\hline Observations & 3,833 & 3,833 & 3,833 & 3,835 \\
\hline Countries & 88 & 88 & 88 & 88 \\
\hline Chi-Square & 233.1 & 103.7 & 36.48 & 68.73 \\
\hline Wald Statistics & 0 & 0 & $1.55 \mathrm{e}-09$ & 0 \\
\hline
\end{tabular}

Note: Dependent variable is consumption growth. GMM Dynamic Panel Estimates. Lags 2-4 of consumption growth, all right hand side variables and lagged saving are used as instruments. "XR Practices", "Current Account", "Capital Account", and "Export Proceeds" refer to the binary IMF indicator for restrictions in exchange rate practices, current account, capital account, and repatriation of export proceeds, respectively. For each category, "Open" and "Closed" refers to the binary IMF indicator suggesting "no restrictions" and "at least one restriction", respectively.

Sample period 1966-2011 as dictated by availability of data. Wald Statistics refers to the marginal statistical significance levels of Wald tests that the sensitivity of "Open" observations is equal to that of "Closed" ones, and distributed as $\chi^{2}(1)$. These regressions follow the methodology in Lewis (1997). See footnote 17 for details. 
Table A2: Financial Integration and the Sensitivity of Consumption to Income: Binary Measures

\section{$\underline{\text { All Countries }}$}

\begin{tabular}{lcccc}
\hline IMF & BHL & WW & $\begin{array}{c}\text { Export } \\
\text { Proceeds } \\
\text { [4] }\end{array}$ \\
& [1] & {$[2]$} & {$[3]$} & \\
Output & 0.846 & 0.747 & 0.906 & 0.830 \\
& {$[0.013]^{* * *}$} & {$[0.033]^{* * *}$} & {$[0.034]^{* * *}$} & {$[0.016]^{* * *}$} \\
Output $\times$ De Jure & $\mathbf{- 0 . 0 3 4}$ & $\mathbf{- 0 . 0 9 9}$ & $\mathbf{- 0 . 1 7 8}$ & $\mathbf{- 0 . 0 5 2}$ \\
& {$[0.015]^{* *}$} & {$[0.026]^{* * *}$} & {$[0.037]^{* * *}$} & {$[0.022]^{* *}$} \\
Observations & 3,833 & 2,048 & 2,730 & 3,835 \\
Countries & 88 & 64 & 66 & 88
\end{tabular}

\section{Advanced Economies}

$\begin{array}{lcccc}\text { Output } & 1.075 & 0.752 & 0.742 & 1.045 \\ & {[0.142]^{* * *}} & {[0.178]^{* * *}} & {[0.035]^{* * *}} & {[0.169]^{* * *}} \\ \text { Output } \times \text { De Jure } & & & & \\ & \mathbf{- 0 . 3 9 0} & -0.006 & 0.000 & \mathbf{- 0 . 3 1 8} \\ & {[0.151]^{* * *}} & {[0.186]} & {[0.000]} & {[0.191]^{*}} \\ \begin{array}{l}\text { Observations } \\ \text { Countries }\end{array} & 963 & 945 & 945 & 965 \\ & 22 & 21 & 21 & 22\end{array}$

\section{Developing Economies}

\begin{tabular}{lcccc} 
Output & 0.835 & 0.766 & 0.875 & 0.802 \\
& {$[0.023]^{* * *}$} & {$[0.058]^{* * *}$} & {$[0.074]^{* * *}$} & {$[0.015]^{* * *}$} \\
Output $\times$ De Jure & -0.031 & $\mathbf{- 0 . 1 3 9}$ & $\mathbf{- 0 . 1 4 4}$ & $\mathbf{- 0 . 0 5 2}$ \\
& {$[0.028]$} & {$[0.059]^{* *}$} & {$[0.068]^{* *}$} & {$[0.024]^{* *}$} \\
Observations & 2,870 & 1,376 & 1,785 & 2,870 \\
Countries & 66 & 43 & 45 & 66 \\
\hline
\end{tabular}

Note: Dependent variable is consumption growth. GMM Dynamic Panel Estimates. Lags 2-4 of consumption growth, all right hand side variables and lagged saving are used as instruments. "IMF" refers to the binary IMF indicator for restrictions in capital account. "BHL" and "WW" refer to the stock market liberalization from Bekaert, Harvey and Lumsdaine (2002) trade integration from Wacziarg and Welch (2003), respectively. Export proceeds refers to restrictions on repatriation of export proceeds. Sample period 1966-2011 as dictated by availability of data. 
Table A3. Financial Integration and the Sensitivity of Consumption to Income: De Facto Measures

\section{All Countries}

\begin{tabular}{|c|c|c|c|c|c|c|c|c|}
\hline & \multicolumn{2}{|c|}{ Total Assets } & \multicolumn{2}{|c|}{ Total Liabilities } & \multicolumn{2}{|c|}{ FDI Assets } & \multicolumn{2}{|c|}{ FDI Liabilities } \\
\hline & Chinn-Ito & Quinn & Chinn-Ito & Quinn & Chinn-Ito & Quinn & Chinn-Ito & Quinn \\
\hline Output & $\begin{array}{c}0.926 \\
{[0.011]^{* * *}}\end{array}$ & $\begin{array}{c}1.086 \\
{[0.025]^{* * *}}\end{array}$ & $\begin{array}{c}0.934 \\
{[0.016]^{* * *}}\end{array}$ & $\begin{array}{c}1.123 \\
{[0.014]^{* * *}}\end{array}$ & $\begin{array}{c}0.961 \\
{[0.018]^{* * *}}\end{array}$ & $\begin{array}{c}1.103 \\
{[0.028]^{* * *}}\end{array}$ & $\begin{array}{c}0.948 \\
{[0.009]^{* * *}}\end{array}$ & $\begin{array}{c}1.086 \\
{[0.017]^{* * *}}\end{array}$ \\
\hline $\begin{array}{l}\text { Output } \mathrm{x} \\
\text { De Jure }\end{array}$ & $\begin{array}{c}\mathbf{- 0 . 3 0 5} \\
{[0.012]^{* * *}}\end{array}$ & $\begin{array}{c}-\mathbf{0 . 5 6 8} \\
{[0.044]^{* * *}}\end{array}$ & $\begin{array}{c}-\mathbf{0 . 2 3 8} \\
{[0.025]^{* * *}}\end{array}$ & $\begin{array}{c}\mathbf{- 0 . 5 7 7} \\
{[0.023]^{* * *}}\end{array}$ & $\begin{array}{c}-\mathbf{0 . 3 0 0} \\
{[0.033]^{* * *}}\end{array}$ & $\begin{array}{c}\mathbf{- 0 . 4 9 8} \\
{[0.047]^{* * *}}\end{array}$ & $\begin{array}{c}\mathbf{- 0 . 2 6 1} \\
{[0.025]^{* * *}}\end{array}$ & $\begin{array}{c}\mathbf{- 0 . 5 7 6} \\
{[0.022]^{* * *}}\end{array}$ \\
\hline $\begin{array}{l}\text { Output } \mathrm{x} \\
\text { De Facto }\end{array}$ & $\begin{array}{c}0.071 \\
{[0.002]^{* * *}}\end{array}$ & $\begin{array}{c}0.061 \\
{[0.004]^{* * *}}\end{array}$ & $\begin{array}{c}-0.011 \\
{[0.002]^{* * *}}\end{array}$ & $\begin{array}{c}-0.006 \\
{[0.002]^{* * *}}\end{array}$ & $\begin{array}{c}-0.041 \\
{[0.006]^{* * *}}\end{array}$ & $\begin{array}{c}0.085 \\
{[0.036]^{* *}}\end{array}$ & $\begin{array}{c}0.041 \\
{[0.012]^{* * *}}\end{array}$ & $\begin{array}{c}0.196 \\
{[0.022]^{* * *}}\end{array}$ \\
\hline $\begin{array}{l}\text { Observations } \\
\text { Countries }\end{array}$ & $\begin{array}{c}3,517 \\
88\end{array}$ & $\begin{array}{c}3,294 \\
85\end{array}$ & $\begin{array}{c}3,519 \\
88\end{array}$ & $\begin{array}{c}3,300 \\
85\end{array}$ & $\begin{array}{c}3,507 \\
88\end{array}$ & $\begin{array}{c}3,289 \\
85\end{array}$ & $\begin{array}{c}3,526 \\
88\end{array}$ & $\begin{array}{c}3,308 \\
85\end{array}$ \\
\hline
\end{tabular}

\begin{tabular}{|c|c|c|c|c|c|c|c|c|}
\hline & \multicolumn{2}{|c|}{ Equity Assets } & \multicolumn{2}{|c|}{ Equity Liabilities } & \multicolumn{2}{|c|}{ Debt Assets } & \multicolumn{2}{|c|}{ Debt Liabilities } \\
\hline & Chinn-Ito & Quinn & Chinn-Ito & Quinn & Chinn-Ito & Quinn & Chinn-Ito & Quinn \\
\hline Output & $\begin{array}{c}0.954 \\
{[0.012]^{* * *}}\end{array}$ & $\begin{array}{c}1.117 \\
{[0.019]^{* * *}}\end{array}$ & $\begin{array}{c}0.960 \\
{[0.018]^{* * *}}\end{array}$ & $\begin{array}{c}1.137 \\
{[0.030]^{* * *}}\end{array}$ & $\begin{array}{c}0.918 \\
{[0.007]^{* * *}}\end{array}$ & $\begin{array}{c}1.107 \\
{[0.026]^{* * *}}\end{array}$ & $\begin{array}{c}0.911 \\
{[0.009]^{* * *}}\end{array}$ & $\begin{array}{c}1.133 \\
{[0.018]^{* * *}}\end{array}$ \\
\hline $\begin{array}{l}\text { Output } \mathrm{x} \\
\text { De Jure }\end{array}$ & $\begin{array}{c}\mathbf{- 0 . 2 6 7} \\
{[0.020]^{* * *}}\end{array}$ & $\begin{array}{c}\mathbf{- 0 . 5 1 0} \\
{[0.023]^{* * *}}\end{array}$ & $\begin{array}{c}\mathbf{- 0 . 3 1 0} \\
{[0.024]^{* * *}}\end{array}$ & $\begin{array}{c}\mathbf{- 0 . 5 8 4} \\
{[0.046] * * *}\end{array}$ & $\begin{array}{c}\mathbf{- 0 . 2 5 9} \\
{[0.021]^{* * *}}\end{array}$ & $\begin{array}{c}\mathbf{- 0 . 6 2 8} \\
{[0.041]^{* * *}}\end{array}$ & $\begin{array}{c}\mathbf{- 0 . 1 6 5} \\
{[0.016]^{* * *}}\end{array}$ & $\begin{array}{c}\mathbf{- 0 . 5 7 6} \\
{[0.031]^{* * *}}\end{array}$ \\
\hline $\begin{array}{l}\text { Output } \mathrm{x} \\
\text { De Facto }\end{array}$ & $\begin{array}{c}-0.020 \\
{[0.003]^{* * *}}\end{array}$ & $\begin{array}{c}-0.017 \\
{[0.005]^{* * *}}\end{array}$ & $\begin{array}{c}0.049 \\
{[0.005]^{* * *}}\end{array}$ & $\begin{array}{c}0.134 \\
{[0.006]^{* * *}}\end{array}$ & $\begin{array}{c}0.097 \\
{[0.004]^{* * *}}\end{array}$ & $\begin{array}{c}0.104 \\
{[0.004]^{* * *}}\end{array}$ & $\begin{array}{c}-0.025 \\
{[0.005]^{* * *}}\end{array}$ & $\begin{array}{c}-0.045 \\
{[0.005]^{* * *}}\end{array}$ \\
\hline $\begin{array}{l}\text { Observations } \\
\text { Countries }\end{array}$ & $\begin{array}{c}3,473 \\
88\end{array}$ & $\begin{array}{c}3,255 \\
85\end{array}$ & $\begin{array}{c}3,490 \\
88\end{array}$ & $\begin{array}{c}3,271 \\
85\end{array}$ & $\begin{array}{c}3,523 \\
88\end{array}$ & $\begin{array}{c}3,300 \\
85\end{array}$ & $\begin{array}{c}3,525 \\
88\end{array}$ & $\begin{array}{c}3,306 \\
85\end{array}$ \\
\hline
\end{tabular}

\section{Advanced Economies}

\section{Total Assets}

Chinn-Ito Quinn

Output

Output x

De Jure

Output x

De Facto

Observations

Countries

$[0.415]^{* *} \quad[0.546]^{* *}$

$-0.256$

[0.428]

$-0.706$

0.022

$[0.007]^{* * *}$

0.008

[0.006]

918

22

\section{Total Liabilities}

Chinn-Ito Quinn

1.041

$[0.098]^{* * *}$
$-0.431$

$[0.093]^{* * * *}$

0.032

$[0.006]^{* * *}$

890

22

\section{Developing Economies}

0.966

\section{Total Assets}

Chinn-Ito Quinn

0.870 $[0.016]^{* * *}$

$-0.288$

$[0.106]^{* * *}$

0.009

[0.007] $\mathbf{- 0 . 3 1 8}$

$[0.017]^{* * *}$

0.119 $[0.009]^{* * *}$
1.134 $[0.056]^{* * *}$

$-\mathbf{0 . 8 0 1}$ $[0.123]^{* * *}$

$$
0.179
$$$$
[0.026]^{* * *}
$$

Total Liabilities

Chinn-Ito Quinn

$0.910 \quad 1.226$ $[0.016]^{* * *} \quad[0.036]^{* * *}$

$\mathbf{- 0 . 1 8 5} \quad-\mathbf{0 . 6 7 4}$ $[0.050]^{* * *} \quad[0.058]^{* * *}$

$-0.030 \quad-0.088$ $[0.013]^{* *} \quad[0.013]^{* * *}$

Note: Dependent variable is consumption growth. GMM Dynamic Panel Estimates. Lags 2-4 of consumption growth, all right hand side variables and lagged saving are used as instruments. De Jure refers to financial integration measures of Chinn-Ito and Quinn. De Facto measures refer to financial integration measures such as stocks of assets and liabilities from Lane and Milesi-Ferretti dataset. 
Table A4: Financial Integration and the Sensitivity of Consumption to Income: Country-Specific Features

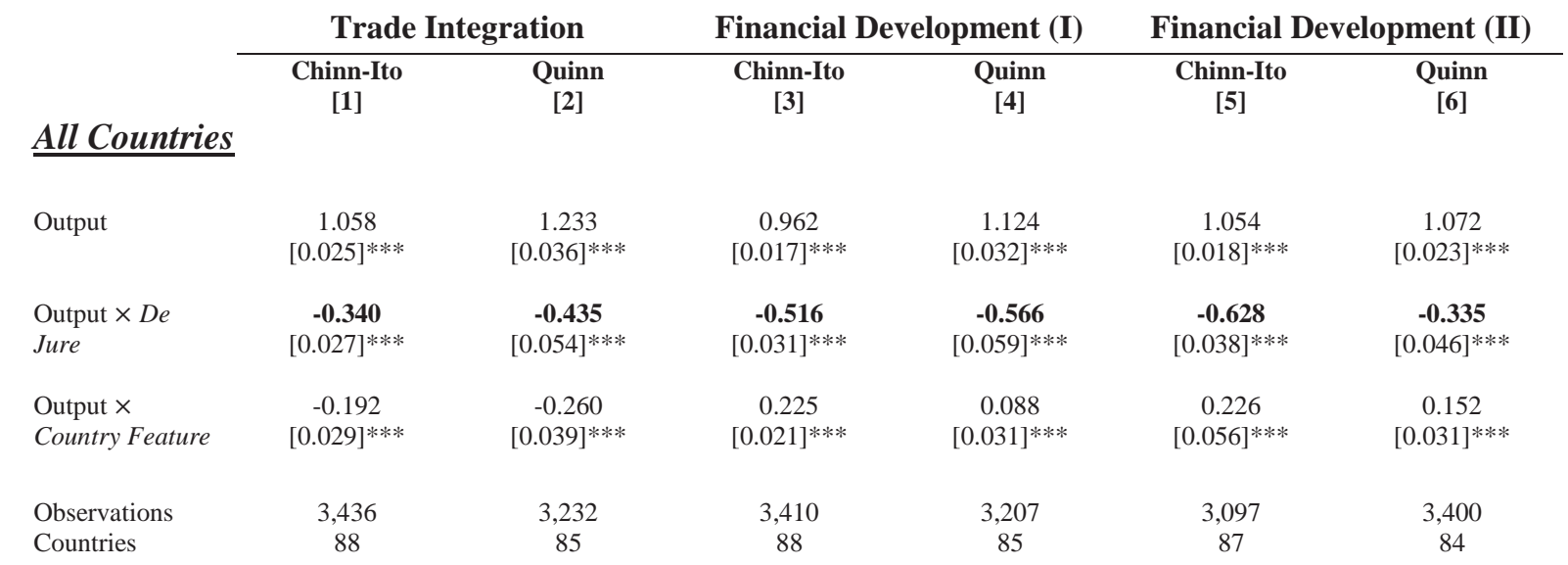

\section{$\underline{\text { Advanced Economies }}$}

\begin{tabular}{|c|c|c|c|c|c|c|}
\hline Output & $\begin{array}{c}0.892 \\
{[0.229]^{* * *}}\end{array}$ & $\begin{array}{c}1.058 \\
{[0.236]^{* * *}}\end{array}$ & $\begin{array}{c}0.839 \\
{[0.156]^{* * *}}\end{array}$ & $\begin{array}{c}1.218 \\
{[0.547]^{* *}}\end{array}$ & $\begin{array}{c}0.926 \\
{[0.264]^{* * *}}\end{array}$ & $\begin{array}{c}1.247 \\
{[0.623]^{* *}}\end{array}$ \\
\hline $\begin{array}{l}\text { Output } \times \text { De } \\
\text { Jure }\end{array}$ & $\begin{array}{c}\mathbf{- 0 . 3 9 0} \\
{[0.215]^{*}}\end{array}$ & $\begin{array}{c}\mathbf{- 0 . 4 0 8} \\
{[0.223]^{*}}\end{array}$ & $\begin{array}{c}\mathbf{- 0 . 6 1 2} \\
{[0.193]^{* * *}}\end{array}$ & $\begin{array}{l}-0.679 \\
{[0.641]}\end{array}$ & $\begin{array}{c}\mathbf{- 0 . 5 2 1} \\
{[0.262]^{* *}}\end{array}$ & $\begin{array}{l}-0.673 \\
{[0.827]}\end{array}$ \\
\hline $\begin{array}{l}\text { Output } \times \\
\text { Country Feature }\end{array}$ & $\begin{array}{c}0.277 \\
{[0.125]^{* *}}\end{array}$ & $\begin{array}{c}0.093 \\
{[0.144]}\end{array}$ & $\begin{array}{c}0.415 \\
{[0.108]^{* * *}}\end{array}$ & $\begin{array}{c}0.164 \\
{[0.089]^{*}}\end{array}$ & $\begin{array}{c}0.359 \\
{[0.174]^{* *}}\end{array}$ & $\begin{array}{c}0.175 \\
{[0.257]}\end{array}$ \\
\hline $\begin{array}{l}\text { Observations } \\
\text { Countries }\end{array}$ & $\begin{array}{c}891 \\
22\end{array}$ & $\begin{array}{c}909 \\
22\end{array}$ & $\begin{array}{c}878 \\
22\end{array}$ & $\begin{array}{c}896 \\
22\end{array}$ & $\begin{array}{c}807 \\
21\end{array}$ & $\begin{array}{c}1,015 \\
21\end{array}$ \\
\hline \multicolumn{7}{|c|}{ Developing Economies } \\
\hline Output & $\begin{array}{c}1.031 \\
{[0.051]^{* * *}}\end{array}$ & $\begin{array}{c}1.296 \\
{[0.048]^{* * *}}\end{array}$ & $\begin{array}{c}0.976 \\
{[0.040]^{* * *}}\end{array}$ & $\begin{array}{c}1.142 \\
{[0.036]^{* * *}}\end{array}$ & $\begin{array}{c}1.049 \\
{[0.043]^{* * *}}\end{array}$ & $\begin{array}{c}1.003 \\
{[0.055]^{* * *}}\end{array}$ \\
\hline $\begin{array}{l}\text { Output } \times \text { De } \\
\text { Jure }\end{array}$ & $\begin{array}{c}\mathbf{- 0 . 3 6 7} \\
{[0.061]^{* * *}}\end{array}$ & $\begin{array}{c}\mathbf{- 0 . 4 5 7} \\
{[0.071]^{* * *}}\end{array}$ & $\begin{array}{c}\mathbf{- 0 . 5 0 1} \\
{[0.054]^{* * *}}\end{array}$ & $\begin{array}{c}\mathbf{- 0 . 5 8 0} \\
{[0.074]^{* * *}}\end{array}$ & $\begin{array}{c}\mathbf{- 0 . 6 7 9} \\
{[0.069] * * *}\end{array}$ & $\begin{array}{c}\mathbf{- 0 . 3 1 2} \\
{[0.099]^{* * *}}\end{array}$ \\
\hline $\begin{array}{l}\text { Output } \times \\
\text { Country Feature }\end{array}$ & $\begin{array}{c}-0.162 \\
{[0.033]^{* * *}}\end{array}$ & $\begin{array}{c}-0.328 \\
{[0.062]^{* * *}}\end{array}$ & $\begin{array}{c}0.137 \\
{[0.073]^{*}}\end{array}$ & $\begin{array}{c}0.045 \\
{[0.064]}\end{array}$ & $\begin{array}{c}0.211 \\
{[0.069]^{* * *}}\end{array}$ & $\begin{array}{c}0.307 \\
{[0.080]^{* * *}}\end{array}$ \\
\hline $\begin{array}{l}\text { Observations } \\
\text { Countries }\end{array}$ & $\begin{array}{c}2,545 \\
66\end{array}$ & $\begin{array}{c}2,323 \\
63\end{array}$ & $\begin{array}{c}2,532 \\
66\end{array}$ & $\begin{array}{c}2,311 \\
63\end{array}$ & $\begin{array}{c}2,290 \\
66\end{array}$ & $\begin{array}{c}2,385 \\
63\end{array}$ \\
\hline
\end{tabular}

Note: Dependent variable is consumption growth. GMM Dynamic Panel Estimates. Lags 2-4 of consumption growth, all right hand side variables and lagged saving are used as instruments. Country-specific feature refers to trade integration and financial development variables. De Jure refers to financial integration measures of Chinn-Ito and Quinn. In regressions [1]-[6], the de jure and country-specific variables are also used as controls. Trade Integration denotes exports plus imports divided by GDP. Financial Development (I) refers to Private Credit as a share of GDP and Financial Development (II) refers to Financial System Deposits as a share of GDP. 
Table A5: Financial Integration and the Sensitivity of Consumption to Income (1994-2011)

\begin{tabular}{|c|c|c|c|c|c|c|}
\hline & $\begin{array}{c}\text { Chinn-Ito } \\
\text { [1] }\end{array}$ & $\begin{array}{l}\text { Quinn } \\
\text { [2] }\end{array}$ & $\begin{array}{c}\text { Chinn-Ito } \\
\text { [3] }\end{array}$ & $\begin{array}{c}\text { Quinn } \\
\text { [4] }\end{array}$ & $\begin{array}{c}\text { Chinn-Ito } \\
\text { [5] }\end{array}$ & $\begin{array}{l}\text { Quinn } \\
\text { [6] }\end{array}$ \\
\hline Output & $\begin{array}{c}1.186 \\
{[0.006]^{* * *}}\end{array}$ & $\begin{array}{c}1.428 \\
{[0.016]^{* * *}}\end{array}$ & $\begin{array}{c}1.188 \\
{[0.007]^{* * *}}\end{array}$ & $\begin{array}{c}1.451 \\
{[0.017]^{* * *}}\end{array}$ & $\begin{array}{c}1.119 \\
{[0.007]^{* * *}}\end{array}$ & $\begin{array}{c}1.341 \\
{[0.017]^{* * *}}\end{array}$ \\
\hline Output $\times$ De Jure & $\begin{array}{c}\mathbf{- 0 . 5 2 9} \\
{[0.009]^{* * *}}\end{array}$ & $\begin{array}{c}\mathbf{- 0 . 7 0 7} \\
{[0.031]^{* * *}}\end{array}$ & $\begin{array}{c}\mathbf{- 0 . 6 3 7} \\
{[0.016]^{* * *}}\end{array}$ & $\begin{array}{c}\mathbf{- 0 . 7 5 6} \\
{[0.032]^{* * *}}\end{array}$ & $\begin{array}{c}\mathbf{- 0 . 4 6 0} \\
{[0.020]^{* * *}}\end{array}$ & $\begin{array}{c}\mathbf{- 0 . 5 5 0} \\
{[0.031]^{* * *}}\end{array}$ \\
\hline $\begin{array}{l}\text { World Interest Rate } \times \\
\text { De Jure }\end{array}$ & & & $\begin{array}{c}0.029 \\
{[0.001]^{* * *}}\end{array}$ & $\begin{array}{c}0.027 \\
{[0.002]^{* * *}}\end{array}$ & & \\
\hline $\begin{array}{l}\text { Country Specific } \\
\text { Interest Rate } \times \text { De Jure }\end{array}$ & & & & & $\begin{array}{c}0.024 \\
{[0.001]^{* * *}}\end{array}$ & $\begin{array}{c}0.024 \\
{[0.001]^{* * *}}\end{array}$ \\
\hline $\begin{array}{l}\text { Observations } \\
\text { Countries }\end{array}$ & $\begin{array}{c}1,580 \\
88\end{array}$ & $\begin{array}{c}1,392 \\
85\end{array}$ & $\begin{array}{c}1,492 \\
88\end{array}$ & $\begin{array}{c}1,340 \\
85\end{array}$ & $\begin{array}{c}1,492 \\
88\end{array}$ & $\begin{array}{c}1,340 \\
85\end{array}$ \\
\hline
\end{tabular}

Advanced Economies

\begin{tabular}{|c|c|c|c|c|c|c|}
\hline Output & $\begin{array}{c}2.248 \\
{[0.184]^{* * *}}\end{array}$ & $\begin{array}{c}1.454 \\
{[0.851]^{*}}\end{array}$ & $\begin{array}{c}3.210 \\
{[0.180]^{* * *}}\end{array}$ & $\begin{array}{c}1.993 \\
{[0.625]^{* * *}}\end{array}$ & $\begin{array}{c}3.266 \\
{[0.216]^{* * *}}\end{array}$ & $\begin{array}{c}1.944 \\
{[0.430]^{* * *}}\end{array}$ \\
\hline Output $\times$ De Jure & $\begin{array}{c}\mathbf{- 1 . 6 0 5} \\
{[0.182]^{* * *}}\end{array}$ & $\begin{array}{c}-0.825 \\
{[0.853]}\end{array}$ & $\begin{array}{c}-2.710 \\
{[0.170]^{* * *}}\end{array}$ & $\begin{array}{c}\mathbf{- 1 . 4 7 6} \\
{[0.643]^{* *}}\end{array}$ & $\begin{array}{c}-2.773 \\
{[0.199]^{* * *}}\end{array}$ & $\begin{array}{c}\mathbf{- 1 . 3 8 2} \\
{[0.455]^{* * *}}\end{array}$ \\
\hline $\begin{array}{l}\text { World Interest Rate } \times \\
\text { De Jure }\end{array}$ & & & $\begin{array}{c}0.178 \\
{[0.051]^{* * *}}\end{array}$ & $\begin{array}{c}0.010 \\
{[0.043]}\end{array}$ & & \\
\hline $\begin{array}{l}\text { Country Specific } \\
\text { Interest Rate } \times \text { De Jure }\end{array}$ & & & & & $\begin{array}{c}0.121 \\
{[0.030]^{* * *}}\end{array}$ & $\begin{array}{l}-0.021 \\
{[0.045]}\end{array}$ \\
\hline $\begin{array}{l}\text { Observations } \\
\text { Countries }\end{array}$ & $\begin{array}{c}394 \\
22\end{array}$ & $\begin{array}{c}392 \\
22\end{array}$ & $\begin{array}{c}372 \\
22\end{array}$ & $\begin{array}{c}371 \\
22\end{array}$ & $\begin{array}{c}372 \\
22\end{array}$ & $\begin{array}{c}371 \\
22\end{array}$ \\
\hline
\end{tabular}

\section{Developing Economies}

\begin{tabular}{|c|c|c|c|c|c|c|}
\hline Output & $\begin{array}{c}1.145 \\
{[0.013]^{* * *}}\end{array}$ & $\begin{array}{c}1.341 \\
{[0.052]^{* * *}}\end{array}$ & $\begin{array}{c}1.103 \\
{[0.021]^{* * *}}\end{array}$ & $\begin{array}{c}1.269 \\
{[0.036]^{* * *}}\end{array}$ & $\begin{array}{c}1.045 \\
{[0.018]^{* * *}}\end{array}$ & $\begin{array}{c}1.205 \\
{[0.041]^{* * *}}\end{array}$ \\
\hline Output $\times$ De Jure & $\begin{array}{c}\mathbf{- 0 . 4 5 3} \\
{[0.026]^{* * *}}\end{array}$ & $\begin{array}{c}\mathbf{- 0 . 5 5 6} \\
{[0.088]^{* * *}}\end{array}$ & $\begin{array}{c}-\mathbf{0 . 4 5 3} \\
{[0.030]^{* * *}}\end{array}$ & $\begin{array}{c}\mathbf{- 0 . 4 0 6} \\
{[0.060]^{* * *}}\end{array}$ & $\begin{array}{c}\mathbf{- 0 . 2 8 9} \\
{[0.041]^{* * *}}\end{array}$ & $\begin{array}{c}\mathbf{- 0 . 2 9 8} \\
{[0.066]^{* * *}}\end{array}$ \\
\hline $\begin{array}{l}\text { World Interest Rate } \times D e \\
\text { Jure }\end{array}$ & & & $\begin{array}{c}0.067 \\
{[0.004]^{* * *}}\end{array}$ & $\begin{array}{c}0.059 \\
{[0.005]^{* * *}}\end{array}$ & & \\
\hline $\begin{array}{l}\text { Country Specific Interest } \\
\text { Rate } \times \text { De Jure }\end{array}$ & & & & & $\begin{array}{c}0.040 \\
{[0.003]^{* * *}}\end{array}$ & $\begin{array}{c}0.038 \\
{[0.004]^{* * *}}\end{array}$ \\
\hline $\begin{array}{l}\text { Observations } \\
\text { Countries }\end{array}$ & $\begin{array}{c}1,186 \\
66\end{array}$ & $\begin{array}{c}1,000 \\
63\end{array}$ & $\begin{array}{c}1,120 \\
66\end{array}$ & $\begin{array}{c}969 \\
63\end{array}$ & $\begin{array}{c}1,120 \\
66\end{array}$ & $\begin{array}{c}969 \\
63\end{array}$ \\
\hline
\end{tabular}

Note: Dependent variable is consumption growth. GMM Dynamic Panel Estimates. Lags 2-4 of consumption growth, all right hand side variables and lagged saving are used as instruments. De Jure refers to financial integration measures of Chinn-Ito and Quinn. In columns [3]-[6], interest rate is also included as a control. Sample period $1960-2011$ or as dictated by availability of data. 